\title{
The Growth Performance of Triplochiton scleroxylon, Terminalia superba and Ceiba pentandra in Pure and Mixed Stands.
}

\author{
Afrifa, A. B. ${ }^{{ }^{*}}$, Ofori-Attah, ${ }^{2}$, Sarpong, A. ${ }^{1}$ \\ ${ }^{1}$ School of Natural Resources, Forest Science Department, UENR, P. O. Box 214, Sunyani, Ghana \\ ${ }^{2}$ Faculty of Forest Resources Technology, KNUST, PMB, Kumasi, Ghana \\ "Corresponding Author: alexander.afrifa@uenr.edu.gh alexafrifa2004@yahoo.com
}

\begin{abstract}
Plantation developers mostly prefer exotic to indigenous tree species in restoration of degraded forests due, perhaps to, inadequate information on indigenous tree plantations to enable them change in that direction. The study was conducted at the Jimira Forest Reserve in the Nkawie Forest District to compare the growth performance of Ceiba pentandra, Terminalia superba and Triplochiton scleroxylonin their pure and mixed stands. Four plots, each divided into four subplots measuring $50 \mathrm{~m} \times 50 \mathrm{~m}$, of one hectare demarcated represented three pure stands of Ceiba pentandra, Terminalia superba and Triplochiton scleroxylon and one mixed stand of the three species. Simple random sampling was used to a subplot from each plotand diameter and height measurements were taken. The mean growth rates in diameter of Ceiba pentandra, Terminalia superba, and Triplochiton scleroxylon in the pure stands and the mixed stand were 1.73 and $1.61 \mathrm{~cm} /$ year; 1.77 and $2.02 \mathrm{~cm} /$ year; and 2.70 and $2.57 \mathrm{~cm} /$ year respectively and those in height were 1.06 and $0.80 \mathrm{~m} /$ year; 1.16 and $1.25 \mathrm{~m} /$ year; and 1.98 and $1.59 \mathrm{~m} /$ year respectively. The statistical analysis carried out to determine the variations in tree diameter and height in the pure and mixed stands indicated no significant differences.
\end{abstract}

Keywords: Growth Performance, Triplochiton scleroxylon, Terminalia superba, Ceiba pentandra, Pure and Mixed Stands.

DOI: $10.7176 / \mathrm{JNSR} / 9-4-07$

\section{Introduction}

Over the past decade the world's forest cover has been rapidly decreasing, with average annual decline rates of $0.22 \%$ between 1990 and 2000 and $0.13 \%$ between 2000 and 2010 (FAO, 2011). Ghana, originally well-endowed with natural forests, is no exception to this general trend. Ghana's extent of forested land declined from 2000 to 2010 with a staggering annual rate of $2.1 \%$, leaving a total forest area of $4,940,000$ ha in 2010 , accounting for about $21.7 \%$ of all land in Ghana (FAO, 2011). The reduction and degradation of the tropical forest affect not only the production of timber but also the global environment as a whole. The loss of biological diversity, both plants and animals through forest degradation threatens the sustainable and harmonious development of the global ecosystem (Lamb and Gilmour, 2003). With this current rate of deforestation and degradation, it is anticipated that about 3 to 8 million biological species, including a large number of less used species, will be wiped off from the surface of the earth by the end of the 21 st century if measures are not put in place (Kobayashi, 2004). Plantation forestry is one way of reducing forest degradation and alleviating the pressure on the natural forests, FAO, (2011), and also meeting future wood needs and demand. The Forestry Department established about 50,000 ha of plantations in the 1970's to offset the wood deficit (Agyeman, Veenedall, Amankwa and Swaine, 1996). However, most of these plantations were limited to exotic tree species. For several reasons there has been a preference for exotic tree species because there is enough information on them, they are fast growing and easy to manage. Foli, Agyeman and Ofosu Asiedu (1997) had reported that some indigenous tree species are faster growing in plantations than in natural forest conditions and may well be faster growing than some of the commonly grown exotic species and therefore encouraged their cultivation in plantations.

Lack of adequate information in plantation establishment with indigenous species deters many prospective forest plantation developers. It is therefore necessary for the Forest Services Division to provide such information, particularly, the gestation period of the species, for its clients. One way of achieving this is by determining the growth rates of the indigenous species that have been used in plantations.

Though monoculture plantations of exotic species have been productive, Cossalter and Pye-Smith, (2003); Odoom, (2002); Sedjo, (1999) and provides wood and fibre for some industrial purposes Bowyer, (2001), they usually fail to provide a wide variety of non-timber products and other ecological services that are essential to sustain rural communities McNamara, Tinh, Erskine, Lamb, Yates and Brown, (2006); Lamb, Erskine and Parrotta, (2005); Hartley, (2002); Lamb, (1998). Indigenous species on the other hand have been identified to have the potential to 
perform well and even do better than most commonly used exotic species (Wagner et al., 2008; Lamb, 1998; Butterfield, 1995). The study was meant to determine the growth rates of Ceiba pentandra, Terminalia superba and Triplochiton scleroxylon in their pure and mixed stands.

\section{Materials and Methods}

\subsection{Study Area}

The study was conducted in a plantation established in 2010 at the Jimira Forest Reserve by the Resource Management and Support Centre (RMSC) of the Forestry Commission of Ghana. The reserve lies in a humid climatic zone with a two-peak rainy season (June and October). The average rainfall is between 1,400 and 1,525 $\mathrm{mm}$. The mean maximum temperature is $30^{\circ} \mathrm{C}$ whilst the mean minimum is $21.7^{\circ} \mathrm{C}$. The maximum monthly average of $32.8^{\circ} \mathrm{C}$ occurs in March and the minimum of $19.9^{\circ} \mathrm{C}$ occurs in January (Addey and Barker, 1995).

It lies between latitudes $6^{0} 17^{\prime}$ and $6^{0} 40^{\prime}$ North and longitudes $1^{0} 50^{\prime}$ and $2^{0} 16^{\prime}$ West. The total area of the reserve is 6,216 ha. Ownership of the reserve is vested in the Golden stool with the stools of Toase, Manso-Nkwanta, and Nkawie as caretakers.

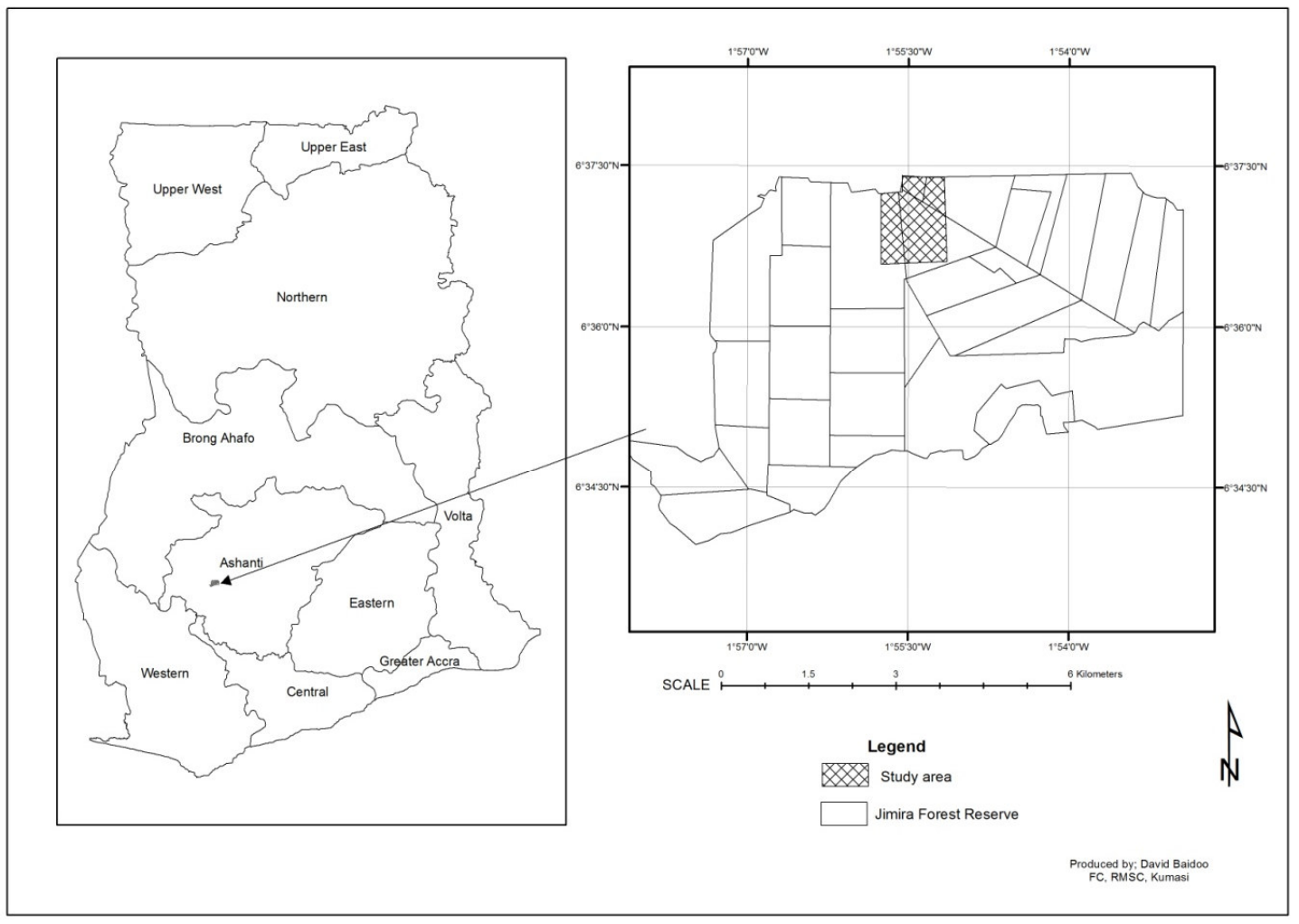

Figure 1 Map of Jimira Forest Reserve showing the study area

The established plantation consist of four plots of one hectare each made up of Ceiba pentandra, Terminalia superba and Triplochiton scleroxylonin pure stands and a mixed stand of the three mentioned species. The pure and the mixed standswere planted at a planting distance of $5 \mathrm{~m} \times 5 \mathrm{~m}$.

Each plot was divided into four subplots measuring 50m x 50m each. A subplot was randomly selected from each plot and the diameters and heights of all the trees within the subplot measured using a Diameter tape and a Suunto Clinometer respectively. Growth rates in diameter and height were determined. 


\section{Results}

3.1 Diameter growth rates for Ceiba pentandra, Terminalia superba and Triplochiton scleroxylon in pure and mixed stands

The mean growth rates in diameter of Ceiba pentandra in the pure and the mixed stands were $1.73 \mathrm{~cm} / \mathrm{year}$ and $1.61 \mathrm{~cm} /$ year respectively. A statistical analysis of variance showed no significant difference in growth rate of the tree diameter at 5\% significant level. The mean growth diameter for Terminalia superb was $1.77 \mathrm{~cm} /$ year and 2.02 $\mathrm{cm} /$ year in the pure and mixed stands respectively. At 5\% level of significance, there was no significant difference in tree diameter for the pure and mixed stands. The results showed $2.70 \mathrm{~cm} /$ year and $2.57 \mathrm{~cm} /$ year mean growth diameter for Triplochiton scleroxylon in the pure and mixed stands respectively. A statistical analysis of variance (ANOVA) at 5\% level of significance indicated no significant difference in tree diameter measurement.

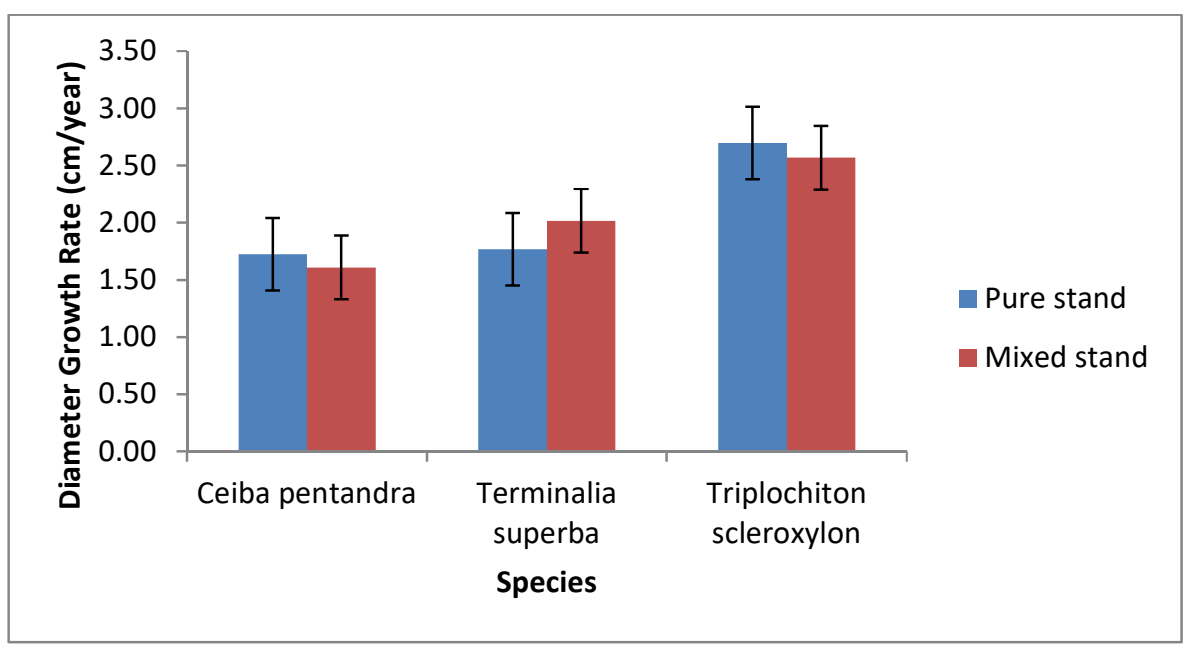

Figure 2 Growth rates in diameter for Ceiba pentandra, Terminalia superba and Triplochiton Scleroxylon

\subsection{Height growth rates for Ceibapentandra, Terminalia superba and Triplochiton scleroxylon in pure and} mixed stands

The mean height growth of Ceiba pentandra in the pure and the mixed stands were $1.06 \mathrm{~m} / \mathrm{year}$ and $0.80 \mathrm{~m} / \mathrm{year}$ respectively. The mean growth rate in height growth for Terminalia superba in the pure and the mixed stands were $1.16 \mathrm{~m} /$ year and $1.25 \mathrm{~m} /$ year respectively. The height growth of Triplochiton scleroxylon in the pure stand was $1.98 \mathrm{~m} /$ year and that of the mixed stand was $1.59 \mathrm{~m} /$ year. A statistical analysis of variance (ANOVA) at $5 \%$ level of significance indicated a significant difference in the mean of tree diameter measurements. Comparing of means using the Least Significant Difference (LSD) method showed a significant difference between the mean heights of Triplochiton scleroxylon in pure and mixed stand. There was however, no significant difference between the mean heights of Ceiba pentandraand Terminalia superba in their pure and mixed stands.

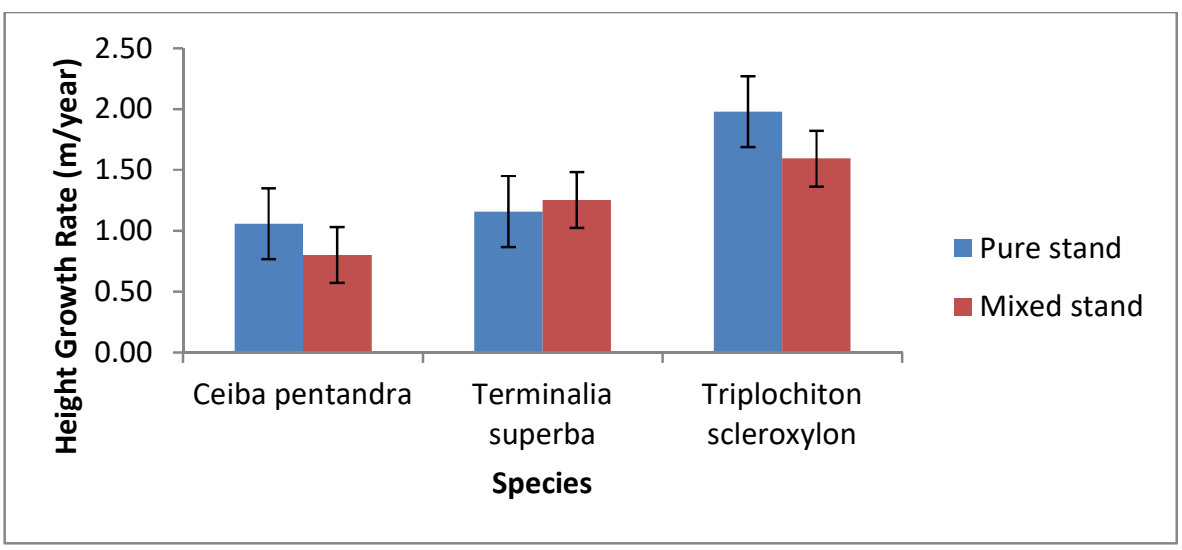


Figure 3 Growth rates in diameter for Ceiba pentandra, Terminalia superba and Triplochiton scleroxylon in pure and mixed forest stand

\section{Discussion}

4.1 Diameter growth rates of Ceiba pentandra, Terminalia superba and Triplochiton scleroxylon in pure and mixed stands

The mean growth in diameter of Ceiba pentandra, Terminalia superba and Triplochiton scleroxylon were higher in the pure stands than in the mixed stands. However, there was no significant difference between the mean growth rate in diameter of the species in their pure and mixed stands at 5\% significant level. Ceiba Pentandra recorded the least growth in diameter in both pure and mixed stand. This was due a disease that attacked Ceiba in its early stages. The disease might be due to failure to treat Ceiba seedlings with fungicides before transporting and subsequent planting.

The higher Ceiba pentandra, Terminalia superba and Triplochiton scleroxylon growth, in diameter observed in mixed stands suggest better performance in mixed stands compared to that in pure stand stands. The higher growth in diameter for Triplochiton scleroxylon than the other species in both the pure and mixed stand could be due to the Celtis-Triplochiton tree association in the ecological zone. The results correspond with several other studies which reported better growth in mixtures than monoculture stands (Potvin and Dutilleul, 2009); (Binkley, Dunkin, DeBell and Ryan, 1992). However, it seems to differ from other studies which suggested greater growth and productivity in some tree species planted in monocultures compared to mixtures. Results from, Petit and Montagnini, (2006) indicated that Calophyllum brasiliense, Virola koschnyi and Hyeronima alchorneoides significantly grew better in monocultures than in mixed plantations. Piotto, Viquez, Montagnini and Kanninen, (2004) also emphasized that in the dry tropics of Costa Rica, Tectona grandis planted in monoculture was the most productive compared to planting in mixture with other species. Araucana cunnighamii planted in the humid tropics of Australia reported by Erskine, Lamb and Bristow, (2006) performed poorly in mixtures with average basal area and stand basal area $16 \%$ and $10 \%$ lower respectively, than in monoculture stands. Thus the concept of productivity of tree species in mixed stand or pure stand may be species specific.

\subsection{Height growth rates of Ceiba pentandra, Terminalia superba and Triplochitonscleroxylon in pure and mixed stands}

The mean growth rate in height of Terminalia superba was higher in the mixed stand than in the pure mixed stand. The mean growth in height for Ceiba pentandra and Triplochiton scleroxylon in pure stands were higher than that of the mixed stands. Ceiba pentandra recorded the least growth in height in both pure and mixed stand. This was due a disease that attacked Ceiba pentandra in its early stages. The disease might be due to failure to treat Ceiba pentandra seedlings with fungicides before transporting and subsequent planting.

The differences in growth rates in height between pure stands and mixed stand could be to competition. Competition is mostly for any one or more factors of light, water and nutrients and the closer any two plants are in their responses to limitations in these variables, the more intense the competition between them (Hunt, Battaglia, Davidson, and Unwin, 2006). 
Competition is one of the most important interactions which can influence productivity and growth in mixed stands of trees. This phenomenon is crucial because in any natural community one species may influence another species directly or indirectly (Hunt et al., 2006); (Cannell, Rothery and Ford, 1984). Therefore, competition is a very important factor which influences growth and survival of individual plants (Firbank and Watkinson, 1985). Several studies have however shown that mixtures can be highly productive compared to monoculture plantations (Nadrowski, Wirth and Scherer-Lorenzen, 2010); (Potvin and Dutilleul, 2009); (Potvin, C. and Gotelli, 2008); (Bristow, Vanclay, Brooks and Hunt, 2006); (Erskine, Lamb and Bristow, 2006); (Forrester, Bauhus, and Cowie, 2005); (DeBell, Cole and Whitesell, 1997); (Binkley, Dunkin, DeBell and Ryan, 1992). The slight differences in growth between pure stands and mixed stand could also be attributed to the genetic composition of the trees and competition among tree species. This assertion is supported by Nwoboshi, (1982) who explained that the pattern of height growth of an individual tree primarily depended upon differences in the genetic composition of the trees. Light is a principal limiting factor for growth in all forest trees as observed by Swaine, Agyeman, Kyere, Orgle, Thompson and Veeneendal, (1997) and hence influences the average height of the trees as they are all light demanding species. The results, however, contrast several other studies which recorded better growth in mixed stands than monoculture stands (Potvin and Gotelli, 2008); (Forrester, Bauhus and Cowie, 2005); (Binkley et al., 1992).

\section{Conclusion}

The research significantly provided the required information for a successful restoration of the degraded forest using indigenous plant species in pure and mixed stands. The Ceiba pentandra, Terminalia superba and Triplochiton scleroxylon planted in mixed stand performed better than the pure stands in diameter and height growth rates.

Triplochiton scleroxylon had the best growth performance in monoculture and mixed stands, followed by Terminalia superba with Ceiba pentandra having the least growth performance.

\section{Acknowledgement}

The authors are very thankful to Dr. Ernest Foli of Forest Research Institute of Ghana (FORIG) and Mrs. Valerie Fumey Nassah of Resource Management Support Centre for their time and invaluable contributions.

\section{References}

Addey, J and Barker, N., (1995). Forest Management Unit 37 management plan for the period of January 1996 to December 2015.Asenanyo and Jimira Forest reserves. Approved by the Chief Conservator of Forests pp 5-9

Agyeman, V. K., Veenedall, E.M., Amankwa, J. O. andSwaine M. D., (1996).Pot size effect on growth performance of some indigenous timber tree seedlings. Ghana Journal of Forestry vol. 2 Pp 14

Binkley, D., Dunkin, K.A., DeBell, D. and Ryan, M.G. (1992). Production and NutrientCycling in Mixed Plantations of Eucalyptus and Albiziain Hawaii.Forest Science, 38:393-408

Bowyer, J.L. (2001). Environmental Implications of Wood Production in IntensivelyManaged Plantations.Wood and fiber science, 33 (3): 318-333

Bristow, M., Vanclay, J., Brooks, L. and Hunt, M. (2006). Growth and Species Interactions of Eucalyptus pellitain a Mixed and Monoculture Plantation in the Humid Tropics of North Queensland.Forest Ecology and Management, 233: 25-294

Butterfield, R.P. (1995). Promoting biodiversity: advances in evaluating native Species for reforestation. Forest Ecology and Management, 75:111-121

Cannell, M.G.R., Rothery, P. and Ford, E.D. (1984). Competition within Stands of Picea Sitchesis and Pinus contorta. Annals of Botany, 53: 349-362

Cossalter, C. and Pye-Smith, C. (2003).Fast-Wood Forestry.Myths and Realities. Forest Perspective, pp.47

DeBell, D.S, Cole, T.G. and Whitesell, C.D. (1997). Growth, Development, and Yield in Pure and Mixed Stands of Eucalyptus and Albizia.Forest Science, 43(2): 286-298

Erskine, P.D., Lamb, D. and Bristow, M. (2006). Tree Species Diversity and Ecosystem Function: can tropical multi-species plantation generate greater productivity. Forest Ecology and Management, 233: 205-210

Evans, J., (1997). Planted Forest of the Wet and Dry Tropics- Their Variety, Nature, and Significance. In: J.R. Boyle, K. Kavanagh, E.C. Jensen, J.K. Winjum (Eds) Proceedings of the symposium on Planted Forests, Contributions to Sustainable Societies. June 1995, Porland

FAO. (2011). Reformingforest tenure: issues, principles and process. FAO Forestry Paper. Rome, Italy (in press). 
Firbank, L. G. and Watkinson, A. R. (1985)On the Analysis of Competition Within Two-Species Mixtures of PlantsJournal of Applied EcologyVol. 22, No. , pp. 503-517

Foli, E.G., Agyeman, V.K. and Ofosu Asiedu, A. (1997).Fast growing species identified for Planting in the Various Ecological Zones in Ghana. Invited paper presented at the Rural Forestry Workshop on Training and Organization of Tree Growers at the National Level. City Hotel, Kumasi. 29-31 July 1997. $10 \mathrm{pp}$.

Forrester, D.I., Shortemeyer, M., Stock, W.D., Bauhus, J., Khanna, P.K.and Cowie, A.L.(2007). Assessing Nitrogen Fixation in Mixed- and Single-species Plantations of

Eucalyptus globules and Acacia mearnsii. Tree Physiology, 27(9): 1319-1328

Forrester, D.I., Bauhus, J. and Cowie, A.L. (2005). On the Success and Failure of Mixed -Species Plantations: lessons learned from model system of Eucalyptus globules and Acacia meansii. Forest Ecology and Management, 209: 147-155

Hartley, M. J. (2002). Rationale and Methods for Conserving Biodiversity in Plantation Forests. Forests Ecology and Management, 155: 81-95

Hunt, M.A., Battaglia, M., Davidson, N.J. and Unwin, G.L. (2006). Competition between Plantation Eucalyptus nitens and Acacia dealbata Weeds in North eastern Tasmania. Forest Ecology and Management, 233: 260-274.

Kobayashi, S. (2004).Landscape Rehabilitation of Degraded Tropical Forest Ecosystems: case study of the CIFOR/Japan Project in Indonesia and Peru. Forest Ecology and Management, 201: 13-22

Lamb, D., Erskine, P.D. and Parrotta, J.A. (2005). Restoration of Degraded Tropical Forest Landscapes.Science, 301: 1628-1632

Lamb, D. and Gilmour, D. (2003).Rehabilitation and Restoration of Degraded Forests.IUCN, Gland, Switzerland and Cambridge, UK and WWF, Gland, Switzerland.110 pp.

Lamb, D. (1998). Large-Scale Ecological Restoration of Degraded tropical ForestLands: the potential role of timber plantation. Restoration Ecology, 6(3): 271-279

McNamara, S., Tinh, D.V., Erskine, P.D., Lamb, D., Yates, D. and Brown, S. (2006).Rehabilitating Degraded lands in Central Vietnam with Mixed Native Species. ForestEcology and Management, 233: 358-365

Nadrowski, K., Wirth, C. and Scherer-Lorenzen, M. (2010). Is Forest Diversity DrivingEcosystem Fucntion and Services?Current Opinion in Environmental Sustainability, 2:75-79

Nwoboshi, L.C., (1982). Tropical silviculture University of Ibadan press pp333.

Odoom, F.K. (2002). Hardwood Plantations in Ghana in Varmola, M. (ed.). ForestPlantations Working Papers. FAO Working Paper FP/24, Rome 2002

Petit and Montagnini, (2006). Growth in pure and mixed plantations of tree species in reforestating rural areas of the humid region of Costa Rica, Central America. Forest Ecology and Management, 233: 338-343.

Piotto D., Viquez E., Montagnini F., and Kanninen M., (2004). Pure and mixed forest plantations with native species of the dry tropics of Costa Rica: a comparison of growth and productivity. Forest Ecology and Management, 190: 359-372.

Piotto, D. (2008). A Meta-analysis Comparing Tree Growth in Monocultures andMixed Plantation.Forests Ecology and Management, 225: 781-786

Potvin, C. andDutilleul, P. (2009). Neighborhood Effects and Size-asymmetric Competition in a Plantation Varying in Diversity.Ecology, 90(2): 321-327

Potvin, C. andGotelli, N.J. (2008). Biodiversity Enhances Individual Performances ButDoes Not Affect Survivorship in Tropical Trees.Ecology letters, 11:217-223

Sedjo, R.A. (1999). The Potential of High-Yield Plantation Forestry for Meeting Timber Needs. New Forests, 17: 339-359

Swaine, M.D., V.K. Agyeman, B. Kyere, T.K. Orgle, J. Thompson and E.M Veeneendal., (1997). Ecology of forest trees of Ghana. OAD Forestry Series No. 7 University of Aberdeen. 76pp.

Wagner, M.R., Cobbinah, J.R. andBosu, P.P. (2008). Forest Entomology in West Africa:Forest insects of Ghana. Second Edition, Springer Publishers, pp. 244

Wagner RM, Atuahene SKN. andCobbinah JR. (1991). Forest Entomology in West Tropical Africa: forest insects of Ghana. Kluwer Academic Publishers, Netherlands. 